\title{
Influence of Udder Hygiene Management on Milk Characteristics in Jersey Cross-Bred Cows at Lower Gangetic Region
}

\author{
Abhishek Paul, Champak Bhakat", D.K. Mandal, A. Mandal, \\ A. Mohammad, A. Chatterjee and S. Rai \\ I/C LPM Section, ERS, NDRI, A-12, Nadia dist, Kalyani-741235, WB, India \\ *Corresponding author
}

\section{A B S T R A C T}

To find out suitable udder hygiene management during milking two rounds study were conducted at adapted village of institute. In first round of study data were collected from 50 farmers having total of 103 milking animal on one page questionnaire regarding management practices, cleaning and hygiene status and then by personally recording management conditions practiced under each household. Based on first round of study, the second round experiment was carried out on 18 lactating Jersey crossbred animals which were divided into three comparable groups (each group content 6 animals) and having

\section{Keywords}

Farmer, Hygiene, Milk characteristics, Lower Gangetic, Somatic cell

Article Info

Accepted: 08 July 2018 Available Online: 10 August 2018 three different management practices viz., Udder washing with soap water (T-1), Udder washing with $1 \%$ solution of Potassium Permanganate (T-2), Udder washing with water only (T-3) as farmer's practice. The compilation and analysis of data of first round study revealed that farmer having $>6$ milking cows, most of them maintaining poor $(53.87 \%)$ hygiene status, cleanliness in their milking cows, housing of animal and milkers who were doing milking operation everyday at farmer's door. The Chi-square test value found to be significant $(\mathrm{P}<0.05)$. The analysis of data of second round experiment revealed that after 60 days of treatment, significant $(\mathrm{P}<0.05)$ differences were recorded among groups. The significantly $(\mathrm{P}<0.05)$ reduction milk SCC was observed in $\mathrm{T}-2$ group followed by $\mathrm{T}-1$ and T-3 group. The milk yield ( $\mathrm{kg} /$ day / animal) was higher in T-2 followed by $\mathrm{T}-1$ and $\mathrm{T}-3$ group. The $\mathrm{pH}$ of milk sample was varied from 6.63 to 6.68 for three groups. The significant $(\mathrm{P}<0.05)$ variation was observed for MCMT grade value. The higher MCMT was recorded in T-3 as compared to T-1 then T-2 group. The MBRT, fat, SNF, protein were varied non-significantly. The study can be concluded that there is a significant association between animal keeping number and hygiene status, cleanliness at farmer's door. The udder hygiene management like regular udder washing with $1 \%$ Potassium Permanganate solution before and after each milking is considered as suitable management practice to reduce somatic cell count and to improve milk production performance of Jersey crossbred cows at lower Gangetic region.

\section{Introduction}

At lower Gangetic region, dairy sector needs urgent improvement in milk production by applying effective management practices. In this region milk productions have not received adequate attention and this has been major obstacle in dairy development, export 
potential of milk and milk products. Also, the vital aspect of clean milk production and udder health still remains a major concern of this area. The milk characteristics in terms of milk composition, yield, somatic cell count (SCC) and quality are important factors for dairy farmer, industry and consumer in this region. The intramammary infections (IMI) due to udder hygiene are serious problems of crossbred dairy animals causing great economic losses due to reduction in milk yield and its value. The poor hygiene status of udder are usually followed by an influx of leucocytes into milk, an increase in its SCC has been used widely as indicating mastitis (Hanan et al., 2015). The SCC is a useful predictor of udder hygiene and, therefore, an important component of milk in assessment aspects of quality, IMI and subclinical mastitis (Patil et al., 2015). The information on suitable management practices with SCC, milk characteristics, IMI, hygiene status, cleanliness at lower Gangetic region are required very much. So, present study was conducted to find out suitable udder hygiene management practices during milking which is effective and easily accepted by dairy farmers of this region.

\section{Materials and Methods}

The whole study was conducted in two rounds at adapted village of ERS, NDRI (Muratipur village of Nadia dist of lower Gangetic region of WB).

\section{First round of study}

For data collection, one paged questionnaire was developed and tested for its suitability of data collection. Information regarding management practices, cleaning and hygiene status followed by farmers were determined by means of a questionnaire. Under different socio-economic conditions the questionnaires were filled after interviewing farmer and then by personally recording different management conditions practiced under each household. Data were collected from 50 farmers having total of 103 milking animal by door to door visits from adapted village. Repeated visits were made to follow up the each and every animals and rapport was also build with dairy farmers. The quantitative and qualitative data were collected through interaction and discussion with farmers, key informants, housewives and secondary sources. To meet objectives of the study both primary and secondary observations were recorded meticulously.

\section{Second round of study}

Based on first round study, farmers were selected who were having more than 6 lactating cows and maintaining poor milk hygiene status. The aim was to see the effect of scientific management practices over farmer's practice. Experiment was carried out on 18 lactating Jersey crossbred animals having almost similar lactation stage, parity, milk yield, which were divided into three comparable groups (each content 6 animals) and having three different management practices Viz., Udder washing with soap water (T-1), Udder washing with $1 \%$ solution of Potassium Permanganate (T-2), Udder washing with water only (T-3) as farmer's practice. In each cases udder washing carried out before and after each milking for 120 days of experimentation.

\section{Milk sample collection and analysis}

A total of 288 milk samples were collected. In each case about $70 \mathrm{ml}$ of sample was collected from whole milk bucket after complete milking of animals in sterilized glass bottles at fortnight interval. Milking time, milk yield and milk extraction rate were recorded in morning and afternoon milking sessions. The SCC in milk sample, $\mathrm{pH}$ of milk and modified 
California mastitis test (MCMT), Methylene Blue reduction test (MBRT), Fat, Protein and SNF were determined in morning and evening milk samples.

\section{Somatic Cell Count in milk}

Udder hygiene was detected by somatic cell count of milk samples which were carried out by an automatic machine of DeLaval cell counter DCC. For cross checking of somatic cell count (SCC) the microscopic procedure was also adapted by using microscopic method of somatic cell count. Before making the smear, the test milk samples were thoroughly mixed by gentle shaking the vials and then $10 \mu \mathrm{l}(0.01 \mathrm{ml})$ of milk measured with micropipette, was taken on the pre drawn one square $\mathrm{cm}$ marked area over a grease free clean glass slide which was uniformly smeared with a standard sterilized bacteriological platinum loop and then the smears were kept for air dry.

The slides were also labeled for respective animal. The dried milk smears stained with modified Newman's Lampert stain and were examined under the oil immersion lens (100X) of the microscope. Thirty different fields per smear were observed and average number of cells per field was then multiplied by the microscopic factor to obtain the number of cells per ml of milk.

The $\mathrm{pH}$ of milk samples were determined by an electronically operated digital $\mathrm{pH}$ meter with glass electrode. The MCMT test was conducted as per procedure described by Devi (1997). The MCMT test is based on the principle of increasing in number of leukocytes and alkalinity of the IMI milk. These changes are due to inflammatory exudation and increased contents of basic salts. Estimation of fat, SNF, protein in milk was performed by automated analyzer (MILKOSCAN).

\section{Methylene Blue Reduction test}

The methylene blue reduction test is based on fact that the colour imparted to milk by the addition of a dye such as methylene blue will disappear more or less quickly. The removal of the oxygen from the milk and the formation of reducing substances during bacterial metabolism cause the colour to disappear. The agencies responsible for the oxygen consumption are the bacteria. Though certain species of bacteria have considerably have more influence than others, it is generally assumed that the greater the number of bacteria in milk, the quicker will the oxygen be consumed, and in turn the sooner will the color disappear. Thus the time of reduction is taken as a measure of the number of organisms in the milk.

The logarithms of SCC number were used for trying to normalize wide variation data distribution. The data were analysed by using one way ANOVA and by Chi-square test (Snedecor and Cochran, 1994). The knowledge level of respondents regarding milking management was also assessed through knowledge index (Bhaskaran and Praveena, 1982).

\section{Results and Discussion}

All dairy farmers of present study area of adapted village (Muratipur) of Nadia dist (WB) use to carry out their daily milking by hand and generally it was done by gowala, a professional milker. All cows were Jersey cross-bred. All lactating cows were fed with additional concentrates according to their milk yield.

\section{Dairy management practices at lower Gangetic region}

In our present study of first round, the hygiene status, cleanliness were assessed meticulously 
in three stages viz., in milking cows itself, at housing of animal and in milkers who were using their hand for milking everyday at farmer's animal. The association between animal keeping number and hygiene status, cleanliness in animals, shed and milkers at farmer's house (Table 1) reveals that farmer having 1 to 2 milking cows, most of them maintaining good $(75.10 \%)$ hygiene status, cleanliness but farmer having $>6$ milking cows, most of them maintaining poor (53.87 $\%$ ) hygiene status, cleanliness where as farmer having 3 to 5 milking cows most of them maintaining medium type $(55.63 \%)$ hygiene status, cleanliness in their milking cows, housing of animal and milkers who were using their hand for milking everyday. The Chisquare test applied over here and value found to be significant $(\mathrm{P}<0.05)$. It was found that the milking places were having not proper drainage and disposal system for both dung, urine and all most all cases the floor were of mud type and there was lack of drainage system.

In lower Gangetic region, the reasons for not following procedures like regular screening of udders or post milking teat dipping were found to be due to low awareness levels and economic reasons. It was also noticed that most of the farmers washed the udders of their lactating cows only in newly calved cows and that to for the first 2-3 days after parturition. Regular screening of udders was not being practiced under village conditions. The reasons for not following post milking udder washing were mainly related to awareness levels. It may be an important factor in influencing udder health and subclinical mastitis. There are several previous report supporting teat dips like Neijenhuis et al., (2001) observed that teat wall and cistern respectively were recovered only after 6 and 3 hours of milking, whereas, complete recovery of the teats took more than 9 hours. In a later study, the group also reported that post- milking teat washing reduced the somatic cell counts of milk. The teat sphincter and leukocytes (somatic cell) provide defence line for external bacterial attacks which ultimately invades by pathogenic organisms resulting in increased level of SCC in milk. Under unhygienic conditions pathological bacteria invade internal mammary tissues and obliterate mammary cell lines. Bhakat et al., (2017a) reported that the practice of washing of hands before each milking varied between $25 \%$ and $32 \%$ of cases of farmer.

The Inter mammary Infection (IMI) lead to changes in glandular tissue of the udder. So it is essential to monitor IMI in dairy cows in order to maintain milk quality and udder health. Bhakat et al., (2017b) reported that IMI can be reduced in machine milking practices in comparison to hand milking practices with higher milk production but without affecting milk quality in Jersey crossbred cows at lower Gangetic region. In these villages, calves were allowed to suckle first few drops of milk. If there was no calf under the cow, then milk was added to the milking bucket.

Milk of all animals managed by a farmer was being collected in a single stainless steel or aluminium bucket irrespective of health condition of animal. The above practices under village conditions were found to be in total disagreement to our advices regarding clean milk production which advocated the discard of fore milk due to high microbial counts (Dang et al., 2004). Also, for clean milk production sick or treated animals should be milked at last and their milk should not be collected in vessels with milk of normal animals. Bhakat et al., (2017c) found that farmer having more than 3 cows, most of them $(50 \%)$ maintaining poor hygiene status, cleanliness in their animal, shed and milkers. Bharti et al., (2017) reported that the rate of incidence of SCM was higher in hind quarters 
and therefore, hind quarter required attention during different udder health management programmes.

Based on result of first round study, animal were selected to start experiment in second round study by providing three different management practices of udder hygiene in three groups having 6 lactating cows. The main reason to conduct second round study was that when number of milking animals at farmer's house hold was increased $(>6)$ then hygiene status and cleanliness decreased Viz., poor status found to be recorded of $53.87 \%$ cases. The compilation and analysis of data of second round of study (Table 2) revealed that somatic cell count in milk significantly $(\mathrm{P}<0.05)$ varied between 3 treatments groups.

After 30 days of experimentation, milk SCC was not varied significantly but after 60 days of experimentation significant $\quad(\mathrm{P}<0.05)$ difference was recorded. The udder washing with $1 \%$ potassium permanganate solution (T2) before and after each milking significantly $(\mathrm{P}<0.05)$ reduced $\mathrm{SCC}$ in milk than soap washing of udder (T-1) and only water washing of udder group (T-3). The higher cell count were observed in T-3 group followed by T-1 and T-2 group after end of experiment. The overall $\log _{10}$ SCC significantly $(\mathrm{P}<0.05)$ varied among groups with lowest SCC x $10^{5}$ (cells $/ \mathrm{ml}$ ) was at $\mathrm{T}-2$ group followed by $\mathrm{T}-1$ and $\mathrm{T}-3$ group. At present study a wide variation in value of retransformation of $\log _{10}$ SCC were also observed clearly.

Hamann (2002) termed the word "Gold Standard" for a somatic cell count of up to 100 $000 \mathrm{cells} / \mathrm{ml}$ and values of milk above 100000 cells/ml results in reduction in the milk production and processing properties of milk. In present study, higher SCC in milk sample was might be due to the reason that constant exposure of animals to pathogens, which help easy entry of organism through streak canal also be responsible for higher rate of infection in animals. In fact streak canal of teats consisted keratinized layer and accumulated cellular debris, which was wax like and having sebum like nature consisting of long chain fatty acids, which provides bacterio-static effects. The breakdown of such streak canal barrier with manual error of hand milking leads to increased frequency of infection with successive increase in lactation number. The changes occur in milk composition and milk yield due to IMI/mastitis and increased SCC level in cow milk in cold dry climate reported by some workers viz: Ballou et al., (1995). Bhakat et al., (2016) reported that the $\log 10$ SCC (cells / ml) were significantly $(\mathrm{P}<0.01)$ higher in IMI cows $(6.55 \pm 0.05)$ as compared to no-IMI cows $(4.05 \pm 0.04)$.

Table.1 Association between animal keeping number and hygiene status, cleanliness in animals, shed and milkers at farmer's house at lower Gangetic area

\begin{tabular}{|c|c|c|c|c|}
\hline Animal number & \multicolumn{4}{|c|}{ Hygiene status, cleanliness (animals, shed, milker) at farmers (\%) household } \\
\hline at farmer's house & Good & Medium & Poor & Overall \\
\hline $\begin{array}{c}1 \text { - } 2 \text { Milking } \\
\text { Cows. }\end{array}$ & 75.10 & 17.34 & 7.56 & 43.17 \\
\hline $\begin{array}{cl}\text { 3-5 } & \text { Milking } \\
\text { Cows. }\end{array}$ & 25.91 & 55.63 & 18.46 & 36.48 \\
\hline$>6$ Milking Cows & 12.11 & 34.02 & 53.87 & 20.35 \\
\hline Overall & 41.39 & 34.26 & 24.35 & \\
\hline Chi-Square & \multicolumn{4}{|c|}{$14.51 *$} \\
\hline
\end{tabular}


Table.2 Mean along with SE of Somatic Cell count in milk sample collected from different treatment groups of animals

\begin{tabular}{|c|c|c|c|c|c|}
\hline Parameters & $\begin{array}{l}\text { Period of } \\
\text { treatment }\end{array}$ & $\begin{array}{c}\text { T-1 } \\
\text { group }\end{array}$ & $\begin{array}{l}\mathrm{T}-2 \\
\text { group }\end{array}$ & $\begin{array}{l}\mathrm{T}-3 \\
\text { group }\end{array}$ & Overall \\
\hline \multirow[t]{4}{*}{$\begin{array}{l}\log _{10} \mathrm{SCC} \\
(\text { Cells / ml) }\end{array}$} & After 30 days & $\begin{array}{c}5.59^{\mathrm{a}} \pm \\
0.43\end{array}$ & $\begin{array}{c}5.58^{\mathrm{a}} \pm \\
0.44\end{array}$ & $\begin{array}{c}5.57^{\mathrm{a}} \pm \\
0.49\end{array}$ & $\begin{array}{c}5.58 \pm \\
0.31\end{array}$ \\
\hline & After 60 days & $\begin{array}{c}5.54^{\mathrm{a}} \pm \\
0.31\end{array}$ & $\begin{array}{c}5.50^{\mathrm{b}} \pm \\
0.29\end{array}$ & $\begin{array}{c}5.61^{\mathrm{c}} \pm \\
0.34\end{array}$ & $\begin{array}{c}5.55 \pm \\
0.22\end{array}$ \\
\hline & After 90 days & $\begin{array}{l}5.40^{\mathrm{a}} \pm \\
0.12\end{array}$ & $\begin{array}{c}5.41^{\mathrm{b}} \pm \\
0.11\end{array}$ & $\begin{array}{l}5.45^{\mathrm{c}} \pm \\
0.14\end{array}$ & $\begin{array}{c}5.42 \pm \\
0.10\end{array}$ \\
\hline & After 120 days & $\begin{array}{l}5.35^{\mathrm{a}} \pm \\
0.10\end{array}$ & $\begin{array}{l}5.33^{\mathrm{b}} \pm \\
0.09\end{array}$ & $\begin{array}{c}5.42^{\mathrm{c}} \pm \\
0.11\end{array}$ & $\begin{array}{c}5.36 \pm \\
0.08\end{array}$ \\
\hline \multicolumn{2}{|c|}{$\begin{array}{l}\text { Over all } \log _{10} \text { SCC } \\
(\text { Cells } / \mathrm{ml})\end{array}$} & $\begin{array}{c}5.47^{\mathrm{a}} \pm \\
0.04\end{array}$ & $\begin{array}{c}5.46^{\mathrm{b}} \pm \\
0.04\end{array}$ & $\begin{array}{l}5.52^{\mathrm{c}} \pm \\
0.05\end{array}$ & $\begin{array}{c}5.48 \pm \\
0.03\end{array}$ \\
\hline \multicolumn{2}{|c|}{$\begin{array}{l}\text { Retransformation of } \log _{10} \\
\text { SCC (Cells / ml) }\end{array}$} & $\begin{array}{l}290404.16 \\
\pm 1.10\end{array}$ & $\begin{array}{l}288403.17 \\
\quad \pm 1.10\end{array}$ & $\begin{array}{c}340728.94 \pm \\
1.12\end{array}$ & $\begin{array}{c}306512.09 \pm \\
1.01\end{array}$ \\
\hline \multicolumn{2}{|c|}{$\begin{array}{l}\mathrm{SCC} \times 10^{5} \\
(\text { Cells } / \mathrm{ml})\end{array}$} & $\begin{array}{c}4.12 \pm \\
0.35\end{array}$ & $\begin{array}{c}3.77 \pm \\
0.28\end{array}$ & $\begin{array}{c}5.59 \pm \\
6.14\end{array}$ & $\begin{array}{c}4.51 \pm \\
0.25\end{array}$ \\
\hline
\end{tabular}

Mean with different superscripts $(a, b, c)$ differ significantly $(\mathrm{P}<0.05)$ from each other.

Table.3 Mean along with SE of characteristic features of milk from different Treatment groups of animals

\begin{tabular}{|c|c|c|c|c|}
\hline Parameters & $\begin{array}{c}\text { T-1 } \\
\text { group }\end{array}$ & $\begin{array}{c}\text { T-2 } \\
\text { group }\end{array}$ & $\begin{array}{c}\text { T-3 } \\
\text { group }\end{array}$ & Overall \\
\hline $\begin{array}{c}\text { Milk Yield } \\
\text { (Kg / day / animal) } \\
\end{array}$ & $\begin{array}{c}6.52^{\mathrm{a}} \pm \\
0.15\end{array}$ & $\begin{array}{c}6.74^{\mathrm{a}} \pm \\
0.13\end{array}$ & $\begin{array}{c}6.44^{\mathrm{a}} \pm \\
0.08\end{array}$ & $\begin{array}{c}6.57 \pm \\
0.07\end{array}$ \\
\hline Milk pH & $\begin{array}{c}6.63^{\mathrm{a}} \pm \\
0.01\end{array}$ & $\begin{array}{c}6.66^{\mathrm{a}} \pm \\
0.01\end{array}$ & $\begin{array}{c}6.68^{\mathrm{a}} \pm \\
0.01\end{array}$ & $\begin{array}{c}6.66 \pm \\
0.01\end{array}$ \\
\hline $\begin{array}{c}\text { MCMT } \\
\text { (grade value) }\end{array}$ & $\begin{array}{c}2.10^{\mathrm{a}} \pm \\
0.12\end{array}$ & $\begin{array}{c}1.93^{\mathrm{b}} \pm \\
0.09\end{array}$ & $\begin{array}{c}2.33^{c} \pm \\
0.13\end{array}$ & $\begin{array}{c}2.12 \pm \\
0.07\end{array}$ \\
\hline $\begin{array}{c}\text { MBRT } \\
\text { (Hrs) }\end{array}$ & $\begin{array}{c}5.50^{\mathrm{a}} \pm \\
0.08\end{array}$ & $\begin{array}{c}5.31^{\mathrm{a}} \pm \\
0.07\end{array}$ & $\begin{array}{c}5.89^{\mathrm{a}} \pm \\
0.10\end{array}$ & $\begin{array}{c}5.57 \pm \\
0.05\end{array}$ \\
\hline $\begin{array}{l}\text { Milking Time } \\
\text { (Minute) }\end{array}$ & $\begin{array}{c}10.35^{\mathrm{a}} \pm \\
0.38\end{array}$ & $\begin{array}{c}10.26^{\mathrm{a}} \pm \\
0.37\end{array}$ & $\begin{array}{c}10.25^{\mathrm{a}} \pm \\
0.34\end{array}$ & $\begin{array}{c}10.28 \pm \\
0.29\end{array}$ \\
\hline $\begin{array}{l}\text { Milk Extraction } \\
\text { Rate (Kg/Minute) }\end{array}$ & $\begin{array}{c}0.64^{\mathrm{a}} \pm \\
0.04\end{array}$ & $\begin{array}{l}0.65^{\mathrm{a}} \pm \\
0.02\end{array}$ & $\begin{array}{c}0.66^{\mathrm{a}} \pm \\
0.03\end{array}$ & $\begin{array}{c}0.65 \pm \\
0.01\end{array}$ \\
\hline $\begin{array}{l}\text { Fat } \\
(\%) \\
\end{array}$ & $\begin{array}{c}5.39^{\mathrm{a}} \pm \\
0.11\end{array}$ & $\begin{array}{c}5.11^{\mathrm{a}} \pm \\
0.16\end{array}$ & $\begin{array}{c}4.94^{\mathrm{a}} \pm \\
0.11\end{array}$ & $\begin{array}{c}5.15 \pm \\
0.08\end{array}$ \\
\hline $\begin{array}{l}\text { SNF } \\
(\%)\end{array}$ & $\begin{array}{c}9.05^{\mathrm{a}} \pm \\
0.04\end{array}$ & $\begin{array}{c}8.95^{\mathrm{a}} \pm \\
0.04\end{array}$ & $\begin{array}{c}9.04^{\mathrm{a}} \pm \\
0.03\end{array}$ & $\begin{array}{c}9.01 \pm \\
0.02\end{array}$ \\
\hline $\begin{array}{c}\text { Protein } \\
(\%)\end{array}$ & $\begin{array}{c}3.74^{\mathrm{a}} \pm \\
0.07\end{array}$ & $\begin{array}{c}3.81^{\mathrm{a}} \pm \\
0.06\end{array}$ & $\begin{array}{c}3.80^{\mathrm{a}} \pm \\
0.05\end{array}$ & $\begin{array}{c}3.78 \pm \\
0.04\end{array}$ \\
\hline
\end{tabular}

Mean with different superscripts $(a, b, c)$ differ significantly $(\mathrm{P}<0.05)$ from each other 
All the developed countries are using milk somatic cell counts (SCC) as a marker to determine the udder hygiene /mammary health and quality of milk (Dang et al., 2007). SCC is also less expensive than microbiological culture (Schukken et al., 2003). Seeing the importance of milk SCC internationally, SCC was conducted in Jersey crossbred cows in field. Somatic cells of milk are white blood cells and epithelial cells, which slough off from the lining of the mammary gland during normal course of milking (Harmon 1994). They are widely used as marker to determine the mammary health or IMI and quality of milk (Dohoo and Meek 1982 and Eberhart et al., 1982). In the present study, higher SCC in T-1 and T-3 groups sample was might be due to reason that the higher chance of poor hygiene. However, differences in the values of fat, protein and SNF were non-significant among different milking management. Contrary to this, Hamann (2002) reported a decrease in SNF in milk content in very high SCC herds (> 4.0 lakhs). Bharti et al., (2015) found that the pendulous udder, flat and inverted teatend, very long and thick teat were more susceptible to intra-mammary infection in Jersey crossbred cows and these traits must be considered accordingly while selecting dairy animals for future milk production.

The mean along with SE of characteristic features of milk from different treatment groups of animals (Table 3 ) revealed that milk yield ( $\mathrm{kg} /$ day / animal) was higher in $\mathrm{T}-2$ group followed by T-1 and T-3 group but variation was found to be non-significant. The $\mathrm{pH}$ of milk sample was varied from $6.63 \pm$ 0.01 to $6.68 \pm 0.01$ for three groups. The significant $(\mathrm{P}<0.05)$ variation was observed for MCMT grade value. The higher MCMT was recorded in $\mathrm{T}-3$ group as compared to $\mathrm{T}$ -1 and $\mathrm{T}-2$ group. The quality test of milk by MBRT reveals that reduction time was varied non-significantly and it was ranged from $5.31 \pm 0.07$ to $5.89 \pm 0.10 \mathrm{hrs}$. Since this MBRT values were more than $5 \mathrm{hrs}$, so all milk sample was graded class-I category. The fat (\%) was varied from $4.94 \pm 0.11$ to $5.39 \pm$ 0.11 in all three groups whereas SNF (\%) was ranged from $8.95 \pm 0.04$ to $9.05 \pm 0.04$. The non-significant variation was recorded for milk composition parameters viz: fat, SNF and protein. The percentage of protein content were ranged from $3.74 \pm 0.07$ to $3.81 \pm 0.06$ in all three groups The non-significant variation were also observed milking time and milk extraction rate among groups.

Major concern in lower Gangetic region was that even the minimal values of milk SCC were on the higher side indicating that mammary gland was under stress in these field conditions. It had been seen that higher SCC due to poor management practices was very critical because more influx of milk SCC not only disrupts the mammary epithelium but also decreases milk quality which in turn leads to lower returns. Several of these issues could be addressed if we were able to link milk quality with payment. In a previous study also, Bailey and Heald (2000) reported that each load of milk picked up at the farm was tested for SCC and premiums or deductions were made on the milk prices based on the SCC quality. Similarly, Hamann (2002) also emphasized the need to combine payment of milk for quality not only with SCC but also with the changes in milk composition. So far there was no such practice being followed at lower Gangetic region, where farmers were paid for their milk according to the fat percentage of milk. The positive advancement of milk intake by consumers should be encouraged by high quality of raw milk in dairy practice (Tancin, 2013). As consumers were becoming more health conscious and general awareness to produce clean milk was increasing, there was a need to educate dairy farmers to follow clean milk production and scientific 
management practices, so that they got a good price for their milk and it matches international quality. Bharti et al., (2015) reported that the IMI and higher SCC adversely affect the milk production and raw milk quality parameters.

The study can be concluded that there was a significant association between animal keeping number and hygiene status, cleanliness at farmer's door. The udder hygiene management like regular udder washing with $1 \%$ Potassium Permanganate solution before and after each milking was considered as the suitable management practice to reduce somatic cell count and to improve milk production performance of Jersey crossbred cows at lower Gangetic region.

\section{Conflict of interest}

None

\section{Acknowledgement}

The authors are highly thankful to the Director, ICAR-NDRI for funding and equally indebted to all dairy farmers who cooperated during experimentation, field work and who helped direct / indirect ways.

\section{References}

Bailey K and Heald C W (2000). Milk Components and Quality: New Methods for Paying Pennsylvania Dairy Farmers, Penn State College of Agricultural Sciences Agricultural Research and Cooperative Extension. http://pubs.cas. psu.edu/FreePubs/pdfs/ua342.pdf.

Ballou, L. U., Pasquini, M., Bremel, R. D., Everson, T. and Dean, S. R. D. (1995). Factors affecting herd milk composition and milk plasmin at four levels of somatic cell counts. Journal Dairy Science, 78: 2186-2195.

Bhakat C, Chatterjee A, Mandal A, Mandal DK, Karunakaran $M$ and Dutta TK (2017c). Effect of cleanliness and hygiene on occurrence of mastitis in crossbred cows in WB. Life Sciences International Research Journal, 4 (1): 10 -14 .

Bhakat C, Chatterjee A, Mandal DK, Karunakaran M, Mandal A, Garai S and Dutta TK (2017b). Milking management practices and IMI in Jersey crossbred cows in changing scenario. Indian Journal of Animal Sciences, 87 (4): 95-100.

Bhakat C, Mandal Ajoy, Mohammad Asif and Rai Saroj (2017a). Factors Affecting Hygienic Milk Production for Farmers of Nadia Dist. Journal of Agricultural Engineering and Food Technology, 4 (1): 13-16.

Bhakat C, Mandal DK, Chatterjee A, Karunakaran M, M Asif, Rai S and Mandal A (2016). Influence of clean milk production on incidence of subclinical mastitis in cows at lower Gangetic regions. Journal of Agricultural Engineering and Food Technology, 3 (3): 248 -252.

Bharti P, Bhakat C, Ghosh M K, Dutta T K and Das R (2015). Relationship among intramammary infection and raw milk parameters in Jersey crossbred cows under hot-humid climate. Journal of Animal Research, 5 (2): 317-320.

Bharti P, Bhakat C, Pankaj PK, Bhat SA, Prakash MA, Thul MR, Japheth KP (2015) Relationship of udder and teat conformation with intra-mammary infection in crossbred cows under hothumid climate, Veterinary World 8(7): 898-901

Bharti P, Bhakat C, Puhle JK and Tamboli P (2017). Interdependence and distribution of subclinical mastitis and 
intra-mammary infection among udder quarters in Jersey crossbred cows. International Journal of Agriculture Sciences, 9 (21); 4235 - 4237. Onlinelttp://www.bioinfopublication.org/jouar chive.php-

Bhaskaran $\mathrm{K}$ and Praveena C (1982).Adoption of improved dry land agricultural technology in an integrated dry land agricultural development project in AP. Indian Journal of Extension Education, 18: 32-39.

Dang A K, Anand S K and Singh M (2004) Mastitis and strategies for its control. Indian Dairyman. Volume 56(1) 27-32.

Dang, A.K. and. Anand, S.K. (2007). Effect of milking systems on the milk somatic cell counts and composition. Livestock Research and Rural Development, 19(6): 1-9.

Devi, B. K., Shukla, P. C. and Bagherwal, R. K. (1997). Incidence of sub-clinical mastitis in cows. Indian Journal of Dairy Science. 50(6): 477- 478.

Dohoo I R and Meek A H (1982). Somatic cell counts in bovine milk. Canadian Veterinary Journal. 23: 119-125.

Eberhart R J, Hutchinson L J and Spencer S B (1982). Relationship of bulk milk tank somatic cell counts to prevalence of intramammary infection and to indices of herd production. Journal of Food Protection. 45: 1125-1128.

Hamann J (2002). Relationships between Somatic cell counts and milk composition. Bulletin of the IDF, 372: 56-59.
Hanan, M., El-Hewairy, Sahar, A., Galal, Hamouda, R. H. and Dohreig, R. M. A. (2015). Immunological and bacteriological findings associated with subclinical mastitis in dairy farm. Life Science Journal, 12(2): 139-146.

Harmon, R. J. (1994). Physiology of mastitis and factors affecting somatic cell count. Journal of Dairy Science, 77: 210321120 .

Neijenhuis F, Barkema $\mathrm{H} \mathrm{W}$, Hogeveen $\mathrm{H}$ and Noordhuizen J P T M (2001). Relationship between teat end callosity and occurrence of clinical mastitis. Journal of Dairy Science. 84: 26642672. http://jds.fass.org/cgi/reprint/ 84/12/2664.pdf.

Patil, M. P., Nagvekar, A. S., Ingole, S. D., Bharucha, S. V. and Palve, V. T. (2015). Somatic cell count and alkaline phosphatase activity in milk for evaluation of mastitis in buffalo. Veterinary World, 8(3): 363-366.

Schukken, Y. H., Wilson, D. J., Welcome, F., Garrison-Tinofsky, L. and Gonzales, R. N. (2003). Monitoring udder health and milk quality using somatic cell counts. Veterinary Research, 34: 579-596.

Snedecor G W and Cochran W G (1994). Statistical methods, Affiliated EastWest press and Iowa State University press, $8^{\text {th }}$ edition.

Tancin, V. (2013). Somatic cell counts in milk of dairy cows under practical conditions. Slovak Journal of Animal Science, 46(1): 31-34.

\section{How to cite this article:}

Abhishek Paul, Champak Bhakat, D.K. Mandal, A. Mandal, A. Mohammad, A. Chatterjee and Rai, S. 2018. Influence of Udder Hygiene Management on Milk Characteristics in Jersey Cross-Bred Cows at Lower Gangetic Region. Int.J.Curr.Microbiol.App.Sci. 7(08): 1264-1272. doi: https://doi.org/10.20546/ijcmas.2018.708.143 